$$
\begin{gathered}
\text { STATE OF FLORIDA } \\
\text { STATE BOARD OF CONSERVATION } \\
\text { Ernest Mitts, Director }
\end{gathered}
$$

FLORIDA GEOLOGICAL SURVEY

Robert O. Vernon, Director

INFORMATION CIRCULAR NO. 13

INTERIM REPORT ON THE GROUND-WATER RESOURCES

OF FLAGLER COUNTY, FLORIDA

\author{
By \\ Boris J. Bermes
}

Prepared by

U.S. Geological Survey

in cooperation with the

Florida Geological Survey

Tallahassee, Florida

1958 



\author{
STATE OF FLORIDA \\ STATE BOARD OF CONSERVATION \\ Ernest Mitts, Director
}

FLORIDA GEOLOGICAL SURVEY

Robert O. Vernon, Director

INFORMATION CIRCULAR NO. 13

INTERIM REPORT ON THE GROUND-WATER RESOURCES

OF FLAGLER COUNTY, FLORIDA

By

Boris J. Bermes

Prepared by

U.S. Geological Survey

in cooperation with the

Florida Geological Survey

Tallahassee, Florida

1958 

Abstract. .................. 1

Introduction ............... 2

Previous investigations ............ 3

Well-numbering system........... 3

Geography. ............... 4

Geology................... 4

Ground water............... 8

Nonartesian aquifer .......... 9

Artesian aquifer.................. 10

Piezometric surface of the principal artesian aquifer in Florida......... 12

Piezometric surface in St. Johns, Putnam, and Flagler counties ......... 14

Piezometric surface in Flagler County . . . . 14

Area of artesian flow. ......... 18

Wells................ 18

Quality of water............... 20

Salt-water contamination .......... 22

Summary and conclusions .......... 25

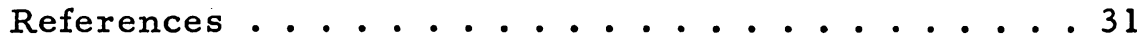

\section{ILLUSTRATIONS}

Figure

1 Map of Florida showing the location of Flagler County .............. 6

2 Generalized geologic section showing the deposits penetrated by wells in Flagler County . 7

3 Graph showing the relation between rainfall at Crescent City and the water level in well 927-115-1 at Bunnell..........11

4 Map of the peninsula of Florida showing the piezometric surface of the principal artesian aquifer ............... 13

5 Map of St. Johns, Putnam, and Flagler counties showing the piezometric surface... 15

6 Map of Flagler County showing the piezometric surface ........... 17 
$7 \quad$ Map of Flagler County showing the approximate areas of artesian flow. . . . . . 19

8 Map of Flagler County showing the locations of wells. ...........21

9 Map of Flagler County showing the approximate chloride content of water from artesian wells................ 24 24

10 Graph showing the relation between the chloride content of the water and the water level in well 920-119-2 near Codys Corner . . 26

11 Graph showing fluctuations of water level in well 928-122-1 and the chloride content of the water in well 928-121-1, west of Bunnell : . 27

Table

1 Analyses of water from wells in Flagler

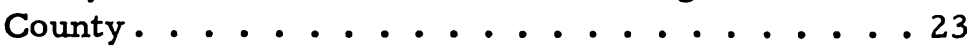




\title{
OF FLAGLER COUNTY, FLORIDA
}

\author{
By \\ Boris J. Bermes
}

\begin{abstract}
Flagler County is in the northeastern part of the Florida Peninsula. The surface of the county is underlain by deposits of sand, marl, shell, and clay to depths ranging from 50 to 150 feet. Beds of coquina and sand in the upper part of the se deposits were mapped by Cooke (1945, pl. 1) as the Anastasia formation and terrace deposits of Pleistocene age. They yield small quantities of nonartesian water of generally low mineral content to shallow screened wells. Beds of marl and phosphatic sand and clay in the lower part of these deposits are believed to be of Miocene or Pliocene age.
\end{abstract}

The deposits of sand, shell, and clay are unconformably underlain by limestone of Eocene age which yields large quantities of artesian water in which the mineralization ranges widely but is generally higher than that of the nonartesian water. The water in the limestone will flow at the surface in the lowlands along the western and eastern edges of the county. The artesian aquifer is recharged within the county and also in adjacent Volusia and Putnam counties.

Records of rainfall and fluctuations of artesian pressure show that in recent years the rainfall was deficient in the western part of the county, and that the artesian pressure head underwent a progressive decline of three feet at Bunnell. Records also show that during this investigation the seasonal decline of pressure head due to pumping for irrigation was about 12 feet in a well west of Bunnell and about five feet in a well near Codys Corner.

The chloride content of water from artesian wells ranges from less than $100 \mathrm{ppm}$ (parts per million) in the recharge areas near the towns of Espanola and Favorita to more than $2,000 \mathrm{ppm}$ in areas in the northeastern part of the county and 
southwest of Bunnell. The chloride content of the artesian water from some wells in certain farm areas increased considerably during periods of heavy pumping.

\section{INTRODUCTION}

Much of the economy of Flagler County is based on the income from winter vegetables which are irrigated with ground water. The demand for ground water is increasing in certain areas of Flagler County. Recently the chloride content of the water from some wells increased, many wells stopped yielding water by natural flow, and a few new wells yielded only salty water. Therefore, the contamination of existing supplies and the availability of new supplies are matters of importance to the economy of the county. In recognition of these and other water problems, the State Legislature appropriated funds for an investigation of the water resources of the county.

The ground-water phase of the investigation was begun in December 1955 by the U.S. Geological Survey in cooperation with the Florida Geological Survey. The purpose of the investigation is to study the ground-water resources of the county and publish the results in a form that will be useful in the solution of ground-water problems.

Studies are being made of the ground-water hydrology and geology of the county with special emphasis on problems associated with salt-water contamination and declining water levels. Major efforts in these studies include the following:

1. Collecting rock cuttings from and pertinent information on depth, yield, etc., on existing wells.

2. Analyzing water samples from existing wells.

3. Making test borings and using well-surveying instruments where necessary.

4. Recording seasonal fluctuations and progressive trends in water level, water quality, water use, and rainfall. 
This report presents a general description of the occurrence of ground water in the county, based on information collected during the first nine months of the investigation.

The investigation was made under the general supervision of A.N. Sayre, Chief, Ground Water Branch, U. S. Geological Survey, and under the immediate supervision of M. I. Rorabaugh, District Engineer for Florida.

\section{Previous Investigations}

The geology and ground-water resources of Flagler County are mentioned in several reports of the U.S. Geological Survey and the Florida Geological Survey.

Cooke $(1945$, p. 268, 295, 304) briefly discusses the occurrence of the Pamlico sand and the Anastasia and Talbot formations in Flagler County. A report by Vernon (1951, fig. 13, 33; pl. 2) includes Flagler County in generalized maps of central Florida which show generalized geologic sections and the structure of the Inglis member of the Moodys Branch formation.

The ground-water resources of Flagler County are briefly mentioned by Stringfield (1936, pl. 6, 10, 12), and chemical analyses of water from wells in Flagler County are included in reports by Collins and Howard (1928, p. 214) and Black and Brown (1951, p. 53).

\section{Well-Numbering System}

All wells inventoried during this investigation were assigned numbers. The well number was assigned by dividing the county into 1-minute quadrangles of latitude and longitude and numbering, consecutively, the wells in each 1-minute quadrangle. The well number is composed of the last three digits of the line of latitude south of the well, followed by the last three digits of the line of longitude east of the well, followed by the number of the well in the quadrangle. Therefore, wells referred to in the text by well number may be located on figure 8 . For example, well 927-115-1 is the well numbered 1 in the quadrangle bounded on the south by latitude $29^{\circ} 27^{\prime}$ and on the east by longitude $81^{\circ} 15^{\prime}$.: 


\section{GEOGRAPHY}

Flagler County is in the northeastern part of the Florida Peninsula (fig. 1) and has an area of 483 square miles, nominally 309,120 acres. The average annual rainfall is about 48 inches, according to the records of the U.S. Weather Bureau.

Topographically, Flagler County includes both lowlands and uplands. The lowlands include the large flat area drained by Haw Creek and its tributaries, and small areas ranging from a few hundred feet to several miles wide adjacent to Crescent Lake, Pellicer Creek, Bulow Creek, the Matanzas River, and the Atlantic Ocean. They range in altitude from sea level, along the Atlantic Ocean, to 25 feet above sea level where they merge into the uplands.

The uplands include the remaining areas of the county. They include a few sand ridges, several lakes, and broad, relatively level areas. Surface altitudes range from 25 feet above sea level, where the uplands adjoin the lowlands to about 50 feet above sea level northwest of Espanola.

The lowlands and some areas of the uplands are drained by streams and canals that discharge into the Atlantic Ocean and $\mathrm{Crescent}$ Lake. The remainder of the uplands are drained, through lakes and swamps, into underlying aquifers, in which the water moves toward streams or toward the ocean.

According to information compiled in 1955 by the U. S. Dept. Commerce, Census Bureau, Flagler County ranks fourth among the counties of the State in the growing of Irish potatoes and cabbage. Thus, although Flagler County is the fifth smallest county in the State in both population and area, it ranks high in agricultural production. This is due, in part, to the availability of adequate supplies of water from inexpensive wells.

\section{GEOLOGY}

Rock cuttings from wells show that Flagler County is underlain by limestone, clay, shell beds and sand. A generalized geologic cross section, showing the deposits penetrated 
by water wells in the southwestern part of the county, is shown in figure 2 .

The lowermost deposit penetrated by water wells is a thick section of limestone of Eocene age, the top of which is shown schematically by the wavy line in figure 2. The upper part of this limestone section is generally very fossiliferous and relatively pure. It locally consists of numerous echinoid and mollusk fragments, miliolids, and large Foraminifera. Similar limestone has been mapped in northern Florida and assigned to various formations of Eocene age by Vernon (1951, p. 115-171) and others. The limestone has not been studied in sufficient detail in Flagler County to per:mit differentiating of the various formations. It will be referred to in this report as limestone of Eocene age.

The limestone of Eocene age is several hundred feet thick, and its top is an undulating surface 35 to 135 feet below sea level. It is a consolidated rock containing numerous porous and permeable zones which yield large quantities of water to open-hole wells. Most wells in the county draw from it exclusively. The upper part of this limestone was eroded by ancient surface streams and circulating ground water (Stringfield, 1936, p. 124-125). The undulations of its surface and much of the porosity in its upper part are probably the result of the cavities, sinkholes, and stream channels that were formed when the limestone was the surface or buried at shallow depth by the overlying deposits of later ancient seas.

The deposits overlying the limestone consist predominantly of clay, shell, and sand. They are shown as a single unit in figure 2 because the available information is not adequate to permit differentiating the individual beds. However, records from a few wells in Flagler County show that the lower part of the deposits of clay, shell, and sand include beds of green phosphatic clay, gray phosphatic sand, sandy limestone, and shell marl. Beds similar to the se have been mapped in northern Florida and assigned to various formations believed to be Miocene and Pliocene in age by Cooke (1945, pl. 1) and Miocene in age by Vernon (Black and Brown, 1951, fig. 1). The beds overlying the limestone in Flagler County 


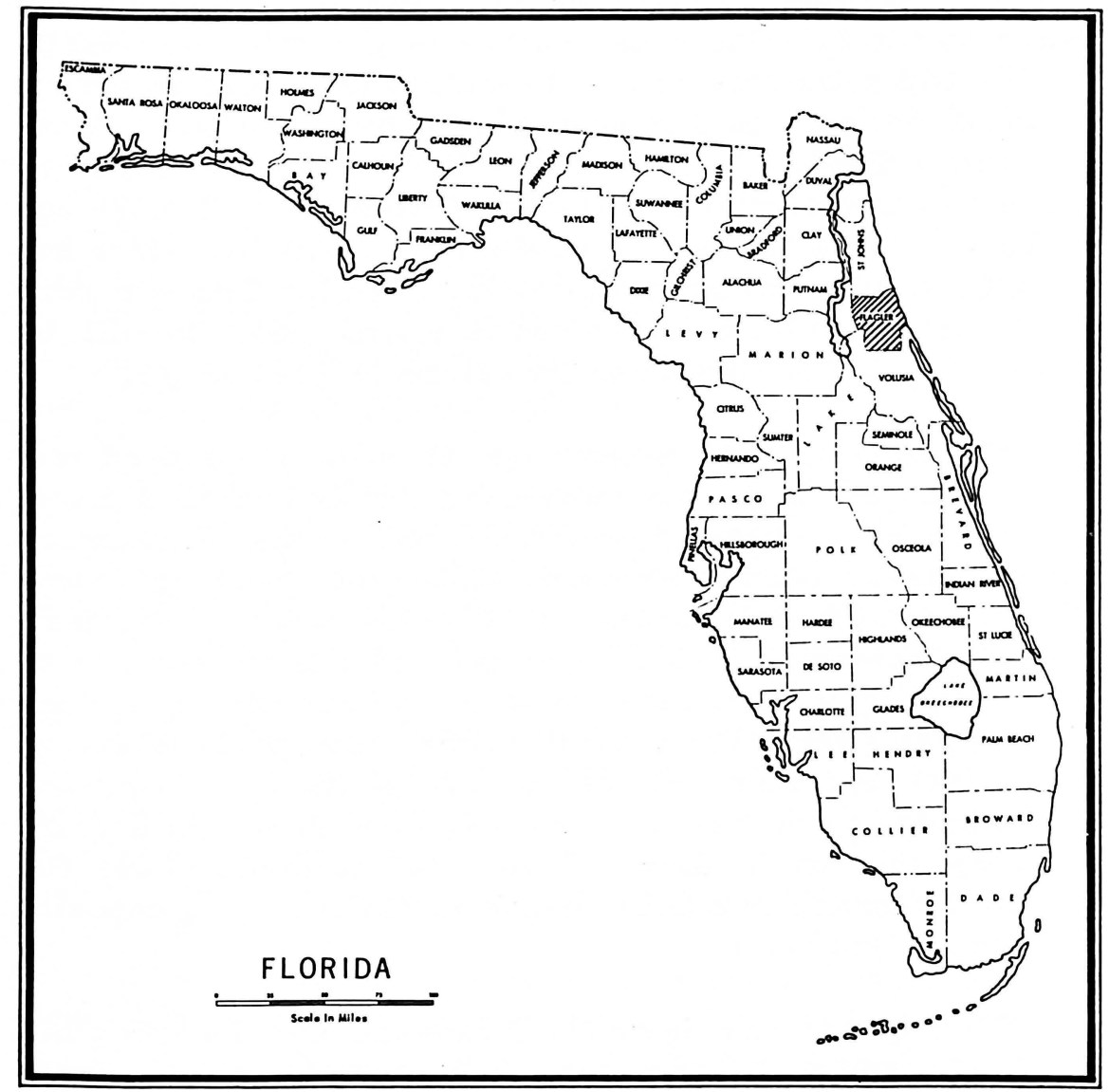

Figure 1. Map of Florida showing the location of Flagler County. 


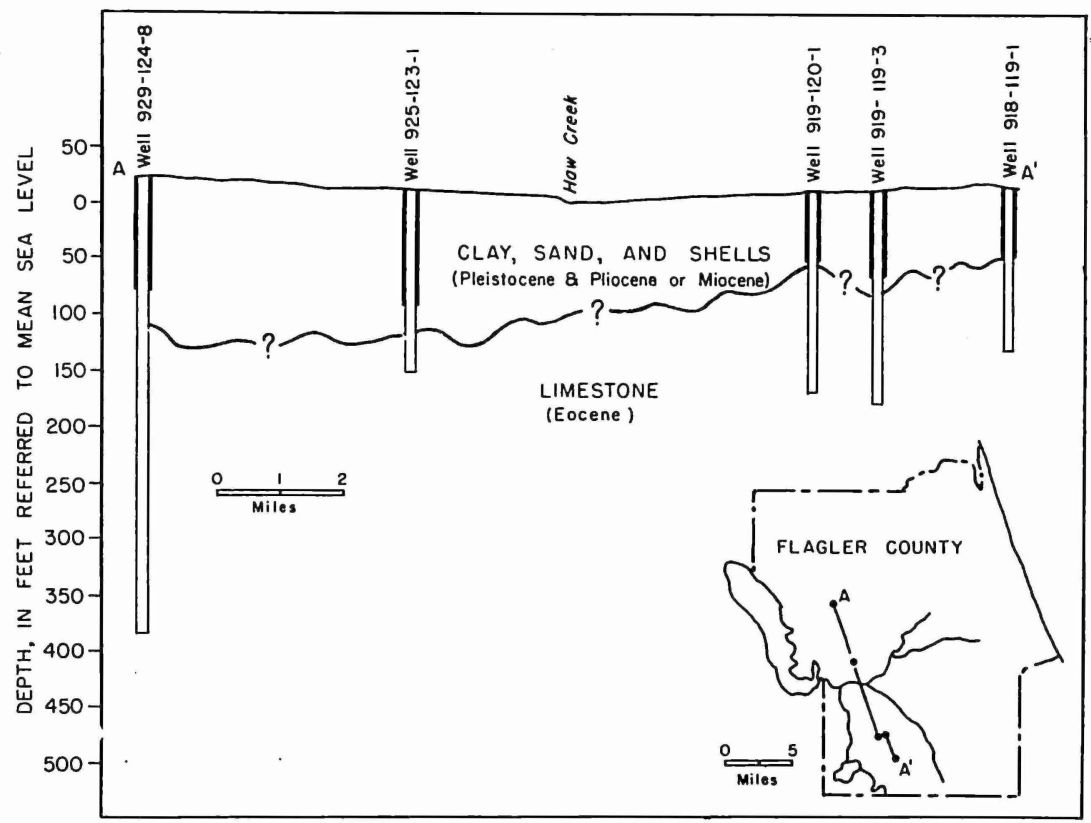

Figure 2. Generalized geologic section showing the deposits penetrated by wells in Flagler County. 
have not been studied in sufficient detail to justify a determination of their correct age. They will be referred to collectively in this report as deposits of Miocene or Pliocene age.

The deposits of Miocene or Pliocene age include relatively impermeable beds that retard the seepage of water into or out of the underlying limestone of Eocene age. Permeable zones in the deposits of Miocene or Pliocene age differ widely in their water-bearing characteristics, and wells drawing more than small quantities of water from them must be fitted with screens. Most wells of large yield are cased through these zones, even in areas where these zones yield water of low mineral content and the underlying limestone yields water of high mineral content.

The upper part of the deposits of clay, shell, and sand include beds of coquina and sand that have been mapped and assigned to the Anastasia formation of Pleistocene age and to terrace deposits of Recent and Pleistocene age by Cooke (1945, pl. 1). The Anastasia formation is at the surface along the entire east coast in Flagler County and extends inland as far as three miles. The terrace deposits are found at the surface throughout the rest of the county. They are thickest under the uplands and thinnest under the lowlands. The deposits of Pleistocene age yield moderate quantities of water to screened wells.

\section{GROUND WATER}

Ground water is the subsurface water in the zone of saturation, the zone in which all the pore spaces are completely filled with water under pressure greater than atmospheric. It is derived almost entirely from precipitation. Part of this precipitation returns to the atmosphere by evapotranspiration, part drains overland to lakes and streams; the remainder reaches the zone of saturation to become ground water. Ground water moves more or less laterally, under the influence of gravity, to places of discharge such as wells, springs, lakes, surface streams, or the ocean.

Ground water may occur under either nonartesian (water table) conditions or artesian conditions. Where it is unconfined, its surface is free to rise and fall and it is said to be 
under nonartesian conditions. The upper surface of unconfined ground water is called the water table. Where the water is confined in a permeable bed that is overlain by a relatively impermeable bed so that its surface is not free to rise and fall, it is said to be under artesian conditions. Technically, the term "artesian"is applied to ground water that is confined under sufficient pressure to rise above the top of the permeable bed that contains it, though not necessarily to or above the land surface. The imaginary surface coinciding with the level to which artesian water will rise is called the piezometric surface.

Rocks in the zone of saturation that are permeable enough to yield water in usable quantity to wells and springs are called aquifers. Areas in which an aquifer receives replenishment from infiltration are called recharge areas. Areas in which an aquifer loses water from springs or wells are called discharge areas. Nonartesian aquifers are usually at or near the land surface and receive recharge over most of their area. Artesian aquifers receive recharge in their areas of outcrop or, under certain conditions, where their "confining" beds are leaky or discontinuous.

\section{$\underline{\text { Nonartesian Aquifer }}$}

Ground water in Flagler County occurs under both nonartesian and artesian conditions. The surficial sand and shell deposits of Recent and Pleistocene age contain ground water under nonartesian conditions in all parts of the county except in areas southwest of Bunnell and along Crescent Lake where they are overlain by confining beds of clay and the water is artesian.

Probably less than 100 wells draw water from the nonartesian aquifer in the county. Their yields differ widely, depending upon their construction, but are generally less than $200 \mathrm{gpm}$ (gallons per minute). Water from these wells is used mainly for domestic and public supplies.

The nonartesian aquifer is replenished by infiltration of rain that falls on the county and, probably to a minor degree, by upward leakage from the artesian aquifer in areas where the piezometric surface is above the water table. In addition 
to this natural recharge the nonartesian aquifer probably receives recharge in the truck-farming areas as a result of slow downwardinfiltration of irrigation water. Water is lost from the aquifer by natural discharge through springs, by downward percolation into the artesian aquifer in the upland areas, and by withdrawal from wells.

The chloride content of water from the nonartesian aquifer ranges from less than $10 \mathrm{ppm}$ to more than $340 \mathrm{ppm}$. It is generally lowest in the upland areas where the nonartesian aquifer receives no recharge from the artesian aquifer neither by upward seepage nor by downward seepage of irrigation water pumped from the artesian aquifer.

\section{Artesian Aquifer}

The principal source of water in Flagler County is an artesian aquifer which forms a part of the principalartesian aquifer of the Florida Peninsula and adjacent area. In Flagler County this aquifer is composed of beds of lime stone of Eocene age and some of the beds of sand and shell in the lower part of the Miocene or Pliocene deposits. All these deposits will be referred to, collectively, as the artesian aquifer. Differences in static head at different depths indicate that the artesian aquifer consists of several water-bearing zones that are separated by beds of low permeability.

The height to which the water level will rise in an artesian well is called the artesian pressure head. Fluctuations of the artesian pressure head are caused, in part, by variations in the $r$ ainfall in the recharge area. Therefore, measurements of rainfall in recharge areas and measurements of water levels in wells are needed in a ground-water investigation.

Periodic measurements of the water level in well 927-115-1, at Bunnell, have been made since 1936. The U.S. Weather Bureau has measured the rainfall at Crescent City, in Putnam County, since 1912. Water levels in well 927-115-1 and the rainfall at Crescent City, for the years 1936-1956, are plotted in figure 3 . The graph of the cumulative departure from long-term mean (fig. 3 ) shows that the rainfall was above average during the period 1941-1947 and was about average during the period 1936-1941 and was below 

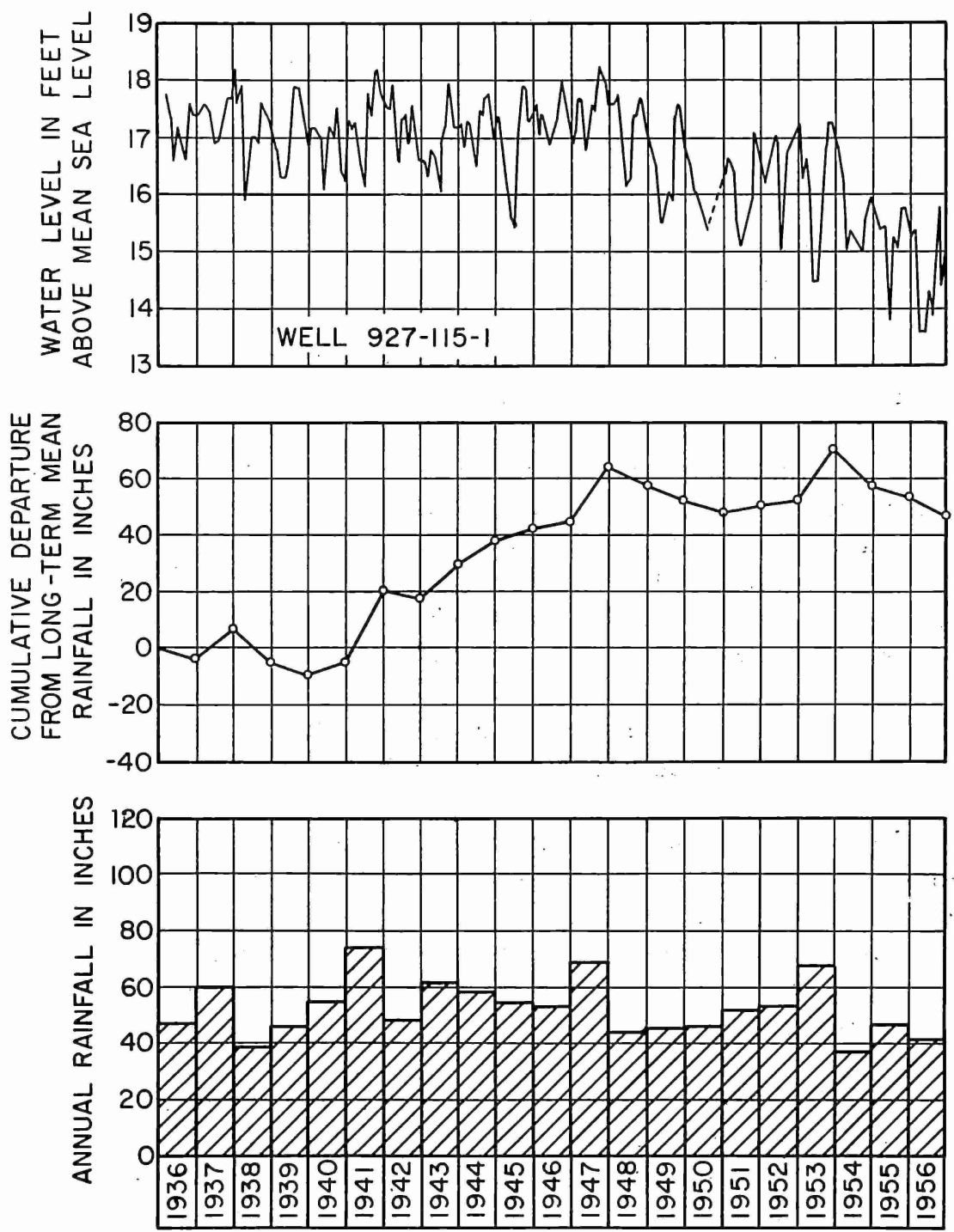

Figure 3. Graph showing the relation between rainfall at Crescent City and the water level in well 927-115-1, at Bunnell. 
average during the period 1954-1956. The graph of the water level shows that during the period of above-average rainfall the highest ground-water levels did not rise above the highest levels of the preceding period of average rainfall. This suggests that there was rejected recharge during the period of above-average rainfall.

The water-level graph shows that the water level declined during the period of near-normal rainfall from 1947 to 1956. If this is the result of increased pumping during that period, it may allow salvage of some otherwise rejected recharge; however, it may indicate instead that rainfall at Crescent City is not representative of rainfall throughout the area.

Measurements are being made periodically - during the current investigation - in approximately 20 other wells, in order to determine the seasonal fluctuations of water levels in different parts of the county. No conclusions have been reached regarding fluctuations of water levels in these wells because the period of record is too short.

\section{Piezometric Surface of the Principal Artesian Aquifer in Florida}

One of the most important parts of an investigation of ground water is the construction of maps representing the altitude of the water levels in wells. Such a map for a nonartesian aquifer shows the altitude and configuration of the water table. For an artesian aquifer it represents the piezometric surface.

The piezometric surface of the principal artesian aquifer in Florida as of 1949 is shown by the contour lines in figure 4. This aquifer consists of limestone deposits of Eocene, Oligocene, and Miocene age that act more or less as a single hydrologic unit. Stringfield (1936, pl. 12) first mapped the piezometric surface and described the aquifer. The shape of the piezometric surface indicates some areas in which the aquifer is replenished and the lateral direction oi .... ovement of the water in the aquifer. Water enters the aquifer in those areas in which the piezometric surface is high and moves along a course perpendicular to the contour lines toward areas in which the piezometric surface is low. 


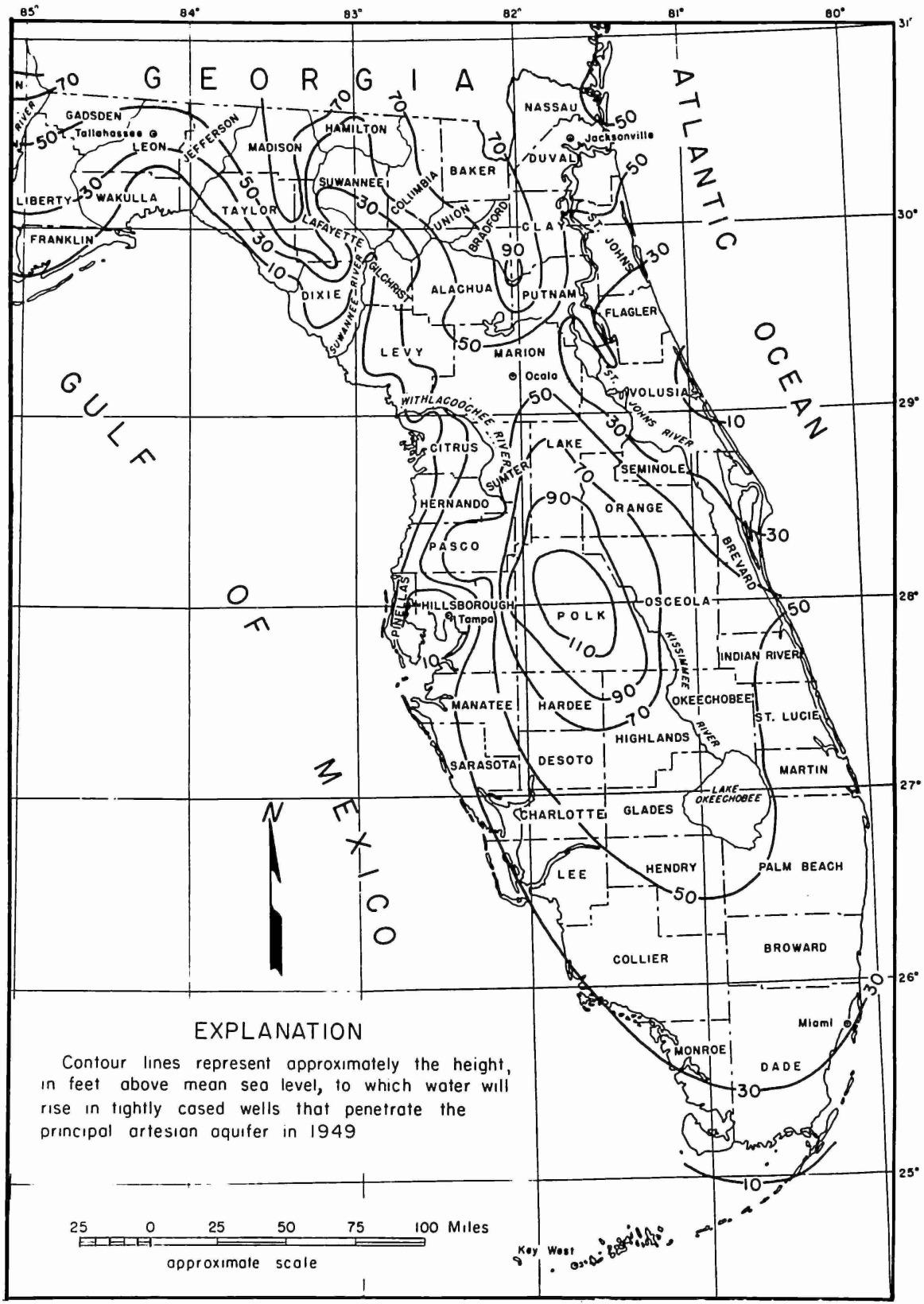

Figure 4. Map of the peninsula of Florida showing the piezometric surface of the principal artesian aquifer. 
One of the notable features of the piezometric surface in Florida, as shown in figure 4, is a broad saddle extending across the State between the areas of recharge in Putnam Count $y$, in the northern part of the peninsula, and Polk County, in the southern part. Throughout most of the State the principal artesian aquifer is generally overlain by relatively impermeable deposits of Miocene age. However, in the area occupied by this saddle, Miocene deposits are thin or absent (Vernon, 1951, fig. 33), thus affording conditions that permit recharge of the aquifer in highlands and discharge from the aquifer in lowlands. Principal areas of recharge and discharge for the artesian aquifer can be determined from figure 4, but many areas of recharge and discharge cannot be determined from that figure. Flagler County, which lies within this saddle, contains local areas of recharge and dis charge that will be discussed in the following sections.

$$
\begin{gathered}
\text { Piezometric Surface in St. Johns, Putnam, } \\
\text { and Flagler Counties }
\end{gathered}
$$

G. R. Tarver (1956) and G. W. Leve (1956), whose inves tigations were made concurrently with this investigation, mapped the piezometric surface in St. Johns County and Putnam County, respectively. Ageneralized map of the piezometric surface of the artesian aquifer in all three counties is shown in figure 5.

Figure 5 shows that some water moves southward from St. Johns County and eastward from Putnam County into Flagler County. It does not show the piezometric surface in Volusia County, but Wyrick (1956, p. 28) has described recharge areas in Volusia County. Some water, therefore, probably moves northward and eastward through the artesian aquifer from the recharge areas in Volusia County into Flagler County.

\section{Piezometric Surface in Flagler County}

A detailed map of the piezometric surface in Flagler County has not yet been made, because determinations of altitude are available for only a few wells. The Flagler County portion of figure 5 shows contours based on the available data as of April 1956. 


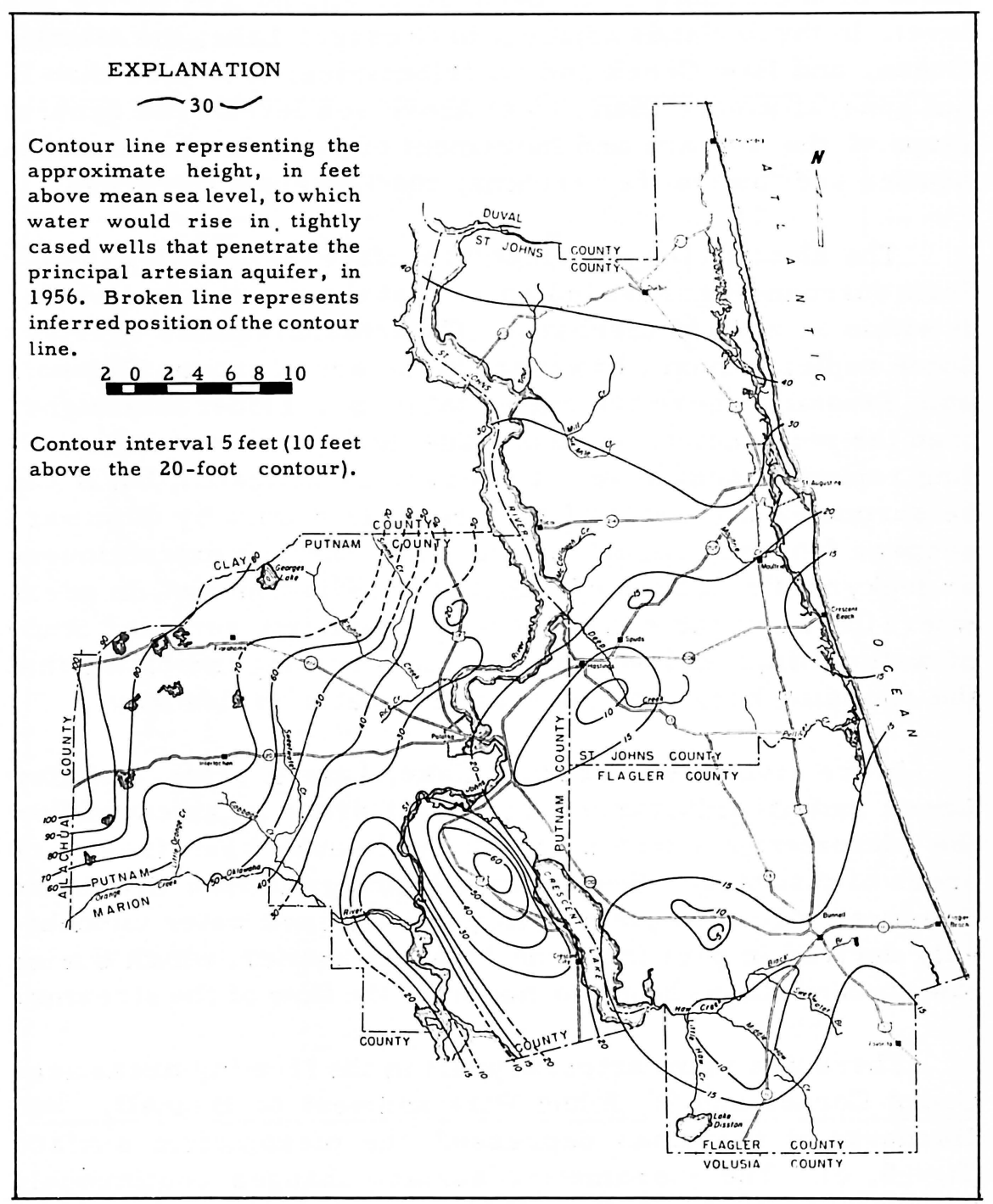

Figure 5. Map of St. Johns, Putnam, and Flagler counties, showing the piezometric surface. 
The piezometric surface in Flagler County is relatively low and flat. In the uplands of the northern and southeastern parts of the county it is between 15 and 20 feet above sea level. In the lowlands adjacent to Crescent Lake, the Atlantic Ocean, and Haw Creek and its tributaries, it is less than 15 but generally more than 10 feet above sea level. The general slope of the surface and movement of water in the artesian aquifer are toward the streams, the lakes and the ocean.

The slope of the piezometric surface into Flagler County from surrounding areas indicates that the county, as a whole, is within an area of discharge. The artesian aquifer receives some replenishment, however, in the areas around Espanola and Favorita where the water table is considerably higher than the piezometric surface. The geologic factors controlling replenishment have not yet been investigated, but it can be surmised that most of the recharge occurs by downward seepage from the nonartesian aquifer through discontinuous or leaky confining beds of Miocene or Pliocene age, in areas where the water table is above the pie zometric surface. Study of well cuttings and well logs reveals nothing indicating that the confining beds may not transmit water in this way.

In the vicinity of Crescent Lake, Lake Disston, and Haw Creek and its tributaries, and other areas of artesian flow the piezometric surface is low, indicating that these are areas of discharge. Several small springs in Haw Creek and Sweetwater Branch yield highly mineralized water undoubtedly derived in part from the artesian aquifer, which during low stream stages helps to maintain the flow of the streams.

There are many artesian wells in the farming areas near Codys Corner and St. Johns Park and west of Bunnell, and discharge of these has depressed the piezometric surface (fig. 5, 6). The piezometric surface changes continuously in response to changes in the rate of recharge, the rate of withdrawal, and other factors. Figure 6 was drawn from water-level measurements made in April 1956, when there was considerable discharge of water from artesian wells for irrigation; therefore, it is only an approximate representation of the piezometric surface at other times. 


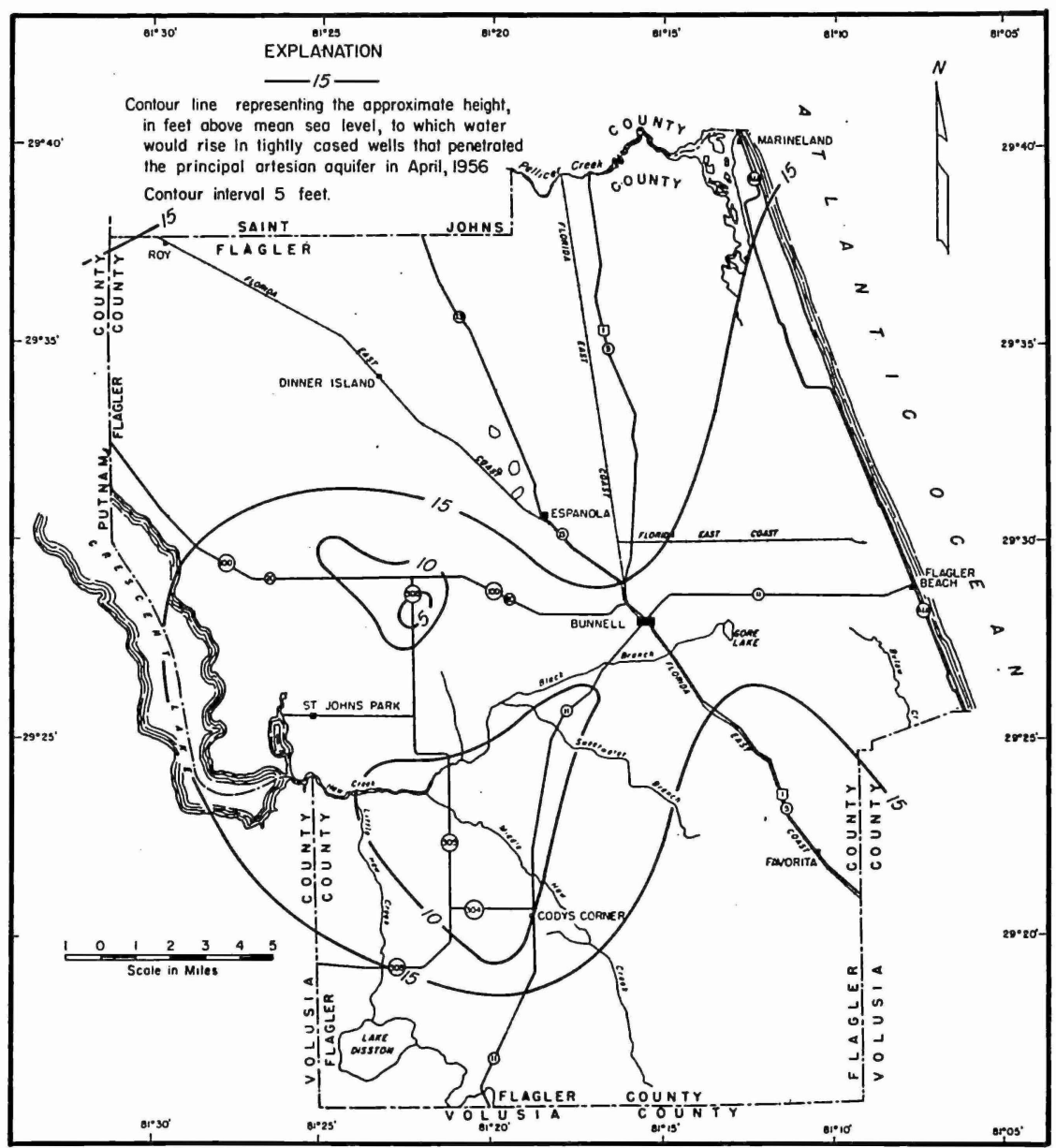

Figure 6. Map of Flagler County showing the piezometric surface. 


\section{Area of Artesian Flow}

Wherever the piezometric surface stands higher than the land surface, artesian wells will flow. The areas of artesian flow in Flagler County in 1956 are shown in figure 7 .

There are two principal areas of artesian flow in the county. One of these occupies a broad band, two or three miles wide, along the Atlantic Ocean, and a narrow westward extension, a few hundred feet wide, along Pellicer Creek shown on figure 7 and its tributaries. In this area there are many smallareas of no artesian flow (some of which are too small to be shown by this map) along the crests of ridges that parallel the coastline. Another principal area of artesian flow occupies an unbroken band along Crescent Lake, up the valleys of Haw Creek and its tributaries, and around Lake Disston. In addition to the principal areas of artesian flow, there is a small area of artesian flow in a stream valleyeast of Roy, in the northwestern part of the county.

In the southwestern part of the county the piezometric surface and the land surface are essentially parallel and at almost the same altitude. The area of artesian flow is, therefore, greatly affected by changes of a few feet in the altitude of the piezometric surface. The area of flow was doubtless very much greater in previous years, when water levels were generally a few feet higher. Water-level measurements made by Stringfield (1936, p. 167) show that artesian wells flowed in June 1934 at Codys Corner, four miles from areas where artesian flow occurred in 1956.

Water-level measurements used to construct figure 7 were made at a time of year (August) when the use of water was slight. The decline in water level due to pumping during the winter growing season will result in a narrowing of the areas of flow shown in figure 7. As the piezometric surface is continuously changing, figure 7 represents the areas of artesian flow only approximately.

\section{Wells}

The locations of at least 70 percent of all the wells in the county and 95 percent of the wells used for irrigation are 


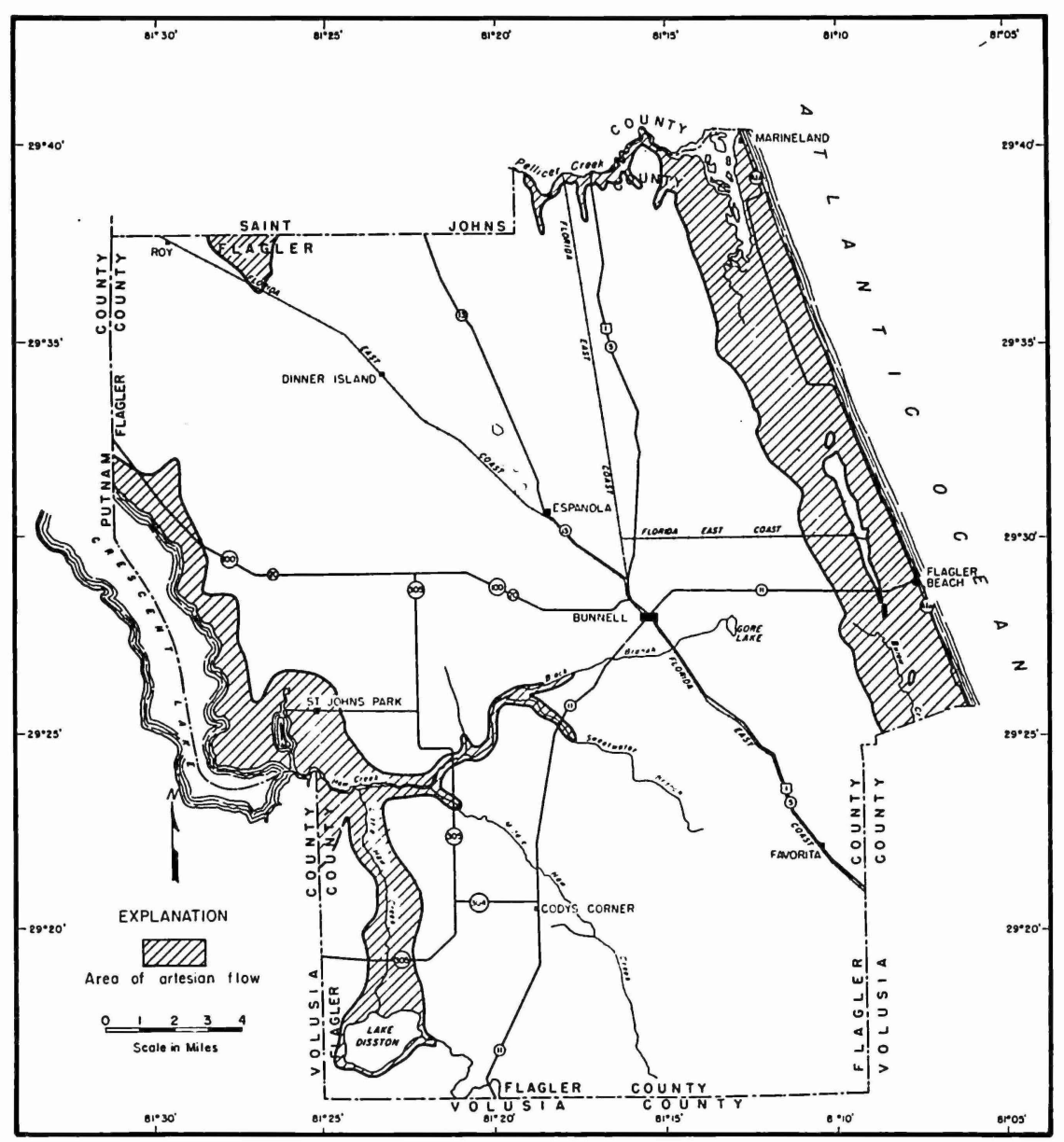

Figure 7. Map of Flagler County showing the approximate areas of artesian flow. 
plotted on figure 8 . Of the 261 wells plotted, 142 are used for irrigation and draw water from the artesian aquifer. Of the remaining 119 wells, $105 \mathrm{draw}$ water from the artesian aquifer and 14 draw water from the nonartesian aquifer.

Figure 8 shows that more than half the wells used for irrigation are in a small area west of Bunnell, and that most of the others are distributed around St. Johns Park and Codys Corner. Most of the ground water used in the county is pumped from the artesian wells in these three farming areas during the winter and spring growing season.

The information collected on wells west of Bunnell and near Codys Corner is considered as being representative of all wells in these two areas. It shows that wells west of Bunnell are 6 to 8 inches in diameter, are 235 to 555 feet deep, and are equipped with electric-powered deep-well turbine pumps or suction pumps, and that wells near Codys Corner are 4 to 6 inches in diameter, are 55 to 326 feet deep, and are pumped by electric and gasoline-powered suction pumps. The wells west of Bunnell, which are relatively deep and equipped with high-capacity pumps, have somewhat higher yields than wells in any other area of the county.

Records of measurements show that ground-water levels declined, during the spring growing season of 1956, from about 8 feet to 18 feet below the land surface in observation well 928-122-1, west of Bunnell, and from about 2 feet to 7 feet below the land surface in observation well 920-119-1, near Codys Corner. The greater decline west of Bunnell undoubtedly is due, in part, to the greater number, closer spacing, and higher discharge of wells in that area. Whether it is also due in part to poorer water-bearing characteristics of the aquifer west of Bunnell has not been determined.

\section{QUALITY OF WATER}

The chemical character of ground water is dependent largely on the type of material with which the water comes in contact. In recharge areas, where the water first enters the ground, it is only slightly mineralized. As the water moves through the ground it dissolves mineral matter from the rocks through which it flows and mixes with any saline water that may be present'. 


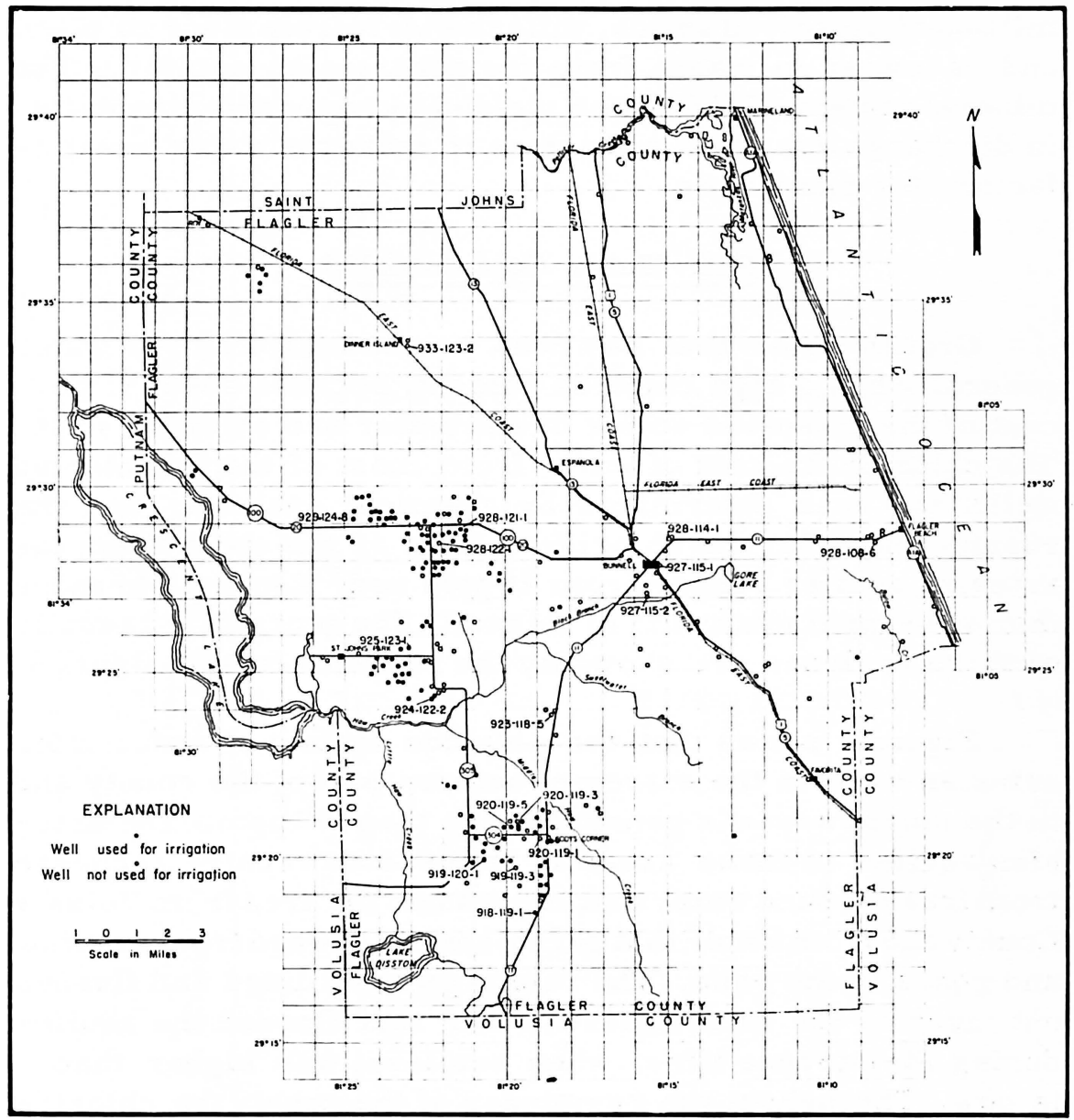

Figure 8. Map of Flagler County showing the locations of wells. 
The mineral content of ground water is determined by chemical analysis of water from wells. The results of chemical analyses of water from wells of various depths in Flagler County are shown in table 1 . The table shows that the mineral content of the ground water, which is expressed in parts per million of dissolved solids, differs widely from place to place and is lowest in water from the nonartesian aquifer. The mineral content of the water yielded by some artesian wells, in discharge areas, is so high as to make the water unsatisfactory for many uses.

\section{Salt-Water Contamination}

Ground water that has been contaminated by sea water generally has a high chloride content, because about 91 percent of the dissolved solids of sea water are chloride salts. The chloride content of water from most of the inventoried wells has been determined by chemical analysis, and the results show that the chloride content of the water from the artesian aquifer ranges from $15 \mathrm{ppm}$ near Espanola to more than 4, $400 \mathrm{ppm}$ southwest of Bunnell. The generalized results of these analyses are shown by the shaded areas in figure 9.

Figure 9 shows that the chloride content of water from artesian wells in the extreme southern part of the county and in the upland areas is generally less than $100 \mathrm{ppm}$. The artesian aquifer in the se areas is believed to receive recharge from fresh ground water that moves into the area from Volusia County and from water that percolates downward from swamps and ponds in the area. The recharge has diluted and flushed out much of the mineralized water that flooded the aquifer during Pleistocene time, when sea level was higher than it is now. Throughout the remainder of the county the chloride content of the artesian water increased with increasing distance from recharge areas (fig. 9). Water from artesian wells in areas where the chloride content exceeds $750 \mathrm{ppm}$ has a salty taste and is undesirable for use as a source of public supply. Water from artesian wells in areas where the chloride content exceeds 2,000 ppm is unsuitable for many uses, including the irrigation of certain crops (Westgate, 1950, p. 116-123).

Water samples collected from wells of different depths show that flushing of the salty water is more complete in 
Table 1. Analyses of Water from Wells in Flagler County

(Chemical constituents in parts per million)

\begin{tabular}{|c|c|c|c|c|c|c|c|c|}
\hline $\begin{array}{l}\text { Well Number } \\
\text { Well Depth } \\
\text { Aquifer } \\
\text { Date of Collection }\end{array}$ & $\begin{array}{c}923-118-5 \\
187 \\
\text { artesian } \\
8-7-56\end{array}$ & $\begin{array}{c}924-122-2 \\
150 ? \\
\text { artesian } \\
8-7-56\end{array}$ & $\begin{array}{c}933-123-2 \\
150 ? \\
\text { artesian } \\
8-7-56\end{array}$ & $\begin{array}{c}927-115-2 \\
180 ? \\
\text { artesian } \\
8-7-56\end{array}$ & $\begin{array}{c}920-119-3 \\
60 \\
\text { artesian } \\
8-10-56\end{array}$ & $\begin{array}{c}920-119-5 \\
165 \\
\text { artesian } \\
8-13-56\end{array}$ & $\begin{array}{c}928-114-1 \\
86^{b} \\
\text { nonartesian } \\
7-16-51 c\end{array}$ & $\begin{array}{c}928-108-6 \\
26^{b} \\
\text { nonartesian } \\
10-30-52^{c}\end{array}$ \\
\hline$\overline{\text { Silica }\left(\mathrm{SiO}_{2}\right)}$ & 17 & 25 & 23 & 14 & 19 & 19 & -- & --- \\
\hline Iron $(F e)$, dissolved ${ }^{a}$ & .09 & .00 & .00 & .05 & .01 & .00 & -- & -- \\
\hline Iron (Fe), total & .89 & .52 & 1.3 & 3.4 & .47 & .68 & 1.5 & 0.0 \\
\hline Calcium (Ca) & 328 & 252 & 184 & 288 & 166 & 108 & 110 & 92 \\
\hline Magnesium (Mg) & 192 & 124 & 71 & 175 & 96 & 34 & 7 & 8 \\
\hline Sodium $(\mathrm{Na})$ & 1,500 & 485 & 210 & 1,070 & 610 & 130 & --- & --- \\
\hline Potassium (K) & 28 & 12 & 7.0 & 20 & 19 & 4.0 & $\ldots$ & -- \\
\hline Bicarbonate $\left(\mathrm{HCO}_{3}\right)$ & 266 & 204 & 212 & 184 & 272 & 292 & 371 & 207 \\
\hline Carbonate $\left(\mathrm{CO}_{3}\right)$ & 0 & 0 & 0 & 0 & 0 & 0 & $\ldots$ & -- \\
\hline Sulfate $\left(\mathrm{SO}_{4}\right)$ & 215 & 218 & 310 & 150 & 140 & 29 & .0 & trace \\
\hline Chloride (Cl) & 3,020 & 1,270 & 500 & 2,500 & 1,290 & 295 & $31^{\circ}$ & 160 \\
\hline Fluoride (F) & .0 & .2 & .4 & .0 & .2 & .3 & .0 & .0 \\
\hline Nitrate $\left(\mathrm{NO}_{3}\right)$ & .8 & .3 & .8 & 1.5 & .5 & 1.2 & & \\
\hline \multicolumn{9}{|l|}{ Dissolved solids } \\
\hline $\begin{array}{l}\text { Sum } \\
\text { Residue on evaporation }\end{array}$ & 5,430 & 2,490 & 1,410 & 4,310 & 2,470 & & & \\
\hline at $180^{\circ} \mathrm{C}$ & -- & -- & --- & -- & $\ldots$ & 852 & $396^{d}$ & $535^{d}$ \\
\hline Hardness as $\mathrm{CaCO}_{3}$ & 1,610 & 1,140 & 751 & 1,440 & 809 & 410 & 304 & 264 \\
\hline $\begin{array}{l}\text { Noncarbonate } \\
\text { Specific conductance }\end{array}$ & 1,390 & 972 & 578 & 1,290 & 586 & 170 & 0 & 94 \\
\hline (micromhos at $25^{\circ} \mathrm{C}$ ) & 9,600 & 4,570 & 2,230 & 7,890 & 4,580 & 1,420 & --- & -- \\
\hline $\mathrm{pH}$ & 7.6 & 7.6 & 7. 7 & 7.5 & 7.8 & 7.8 & 7.0 & 7.6 \\
\hline Color & 6 & 5 & 13 & 4 & 7 & 5 & $\ldots$ & $\ldots$ \\
\hline
\end{tabular}

a In solution at time of analysis.

bAnalysis by Florida State Board of Health.

cDate of analysis.

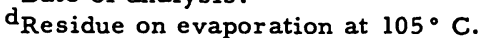




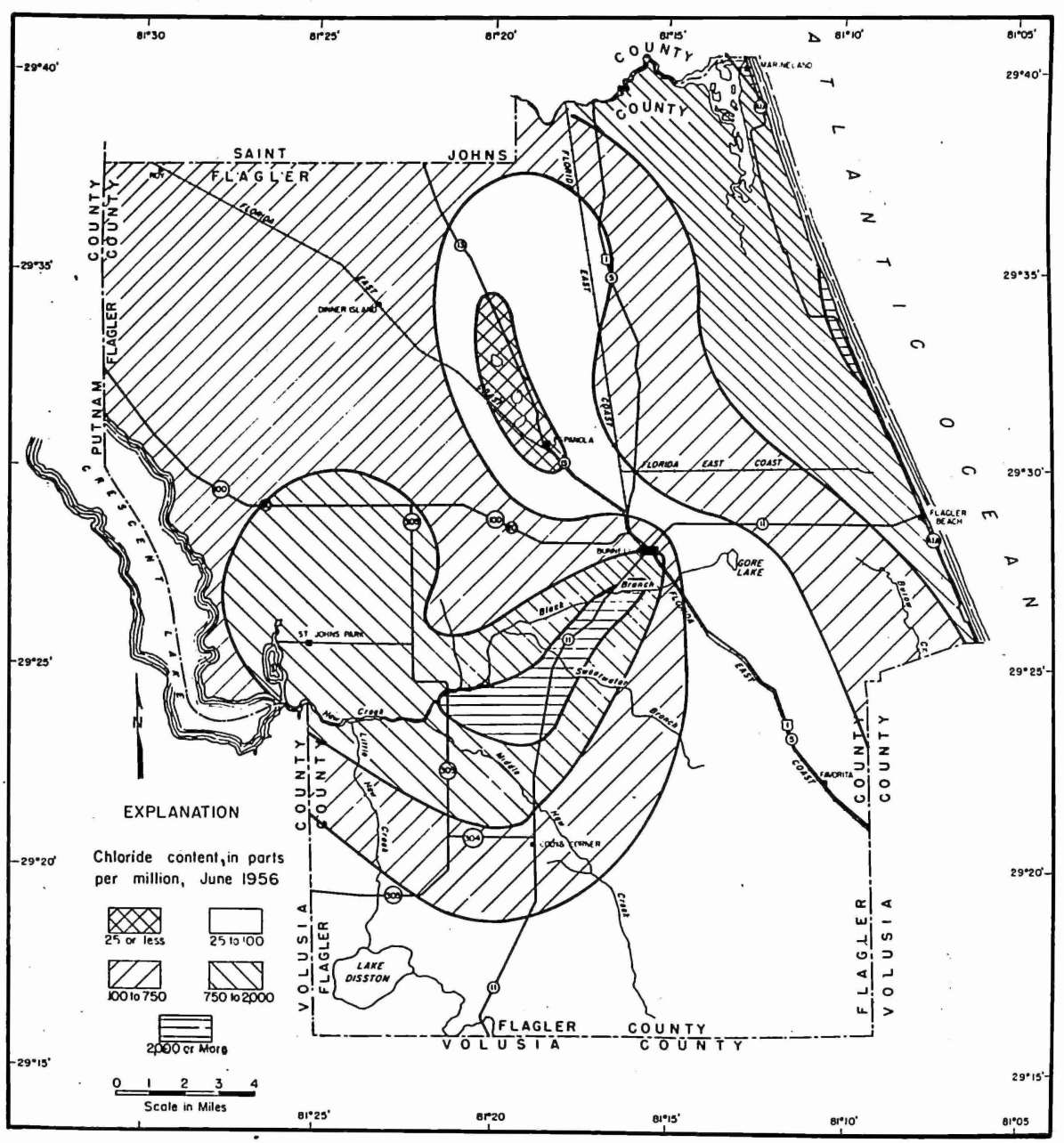

Figure 9. Map of Flagler County showing the approximate chloride content of water from artesian wells. 
some zones of the artesian aquifer than in other zones. West of Bunnell, artesian water yielded by wells drawing from the upper 200 feet of the limestone of Eocene age has a lower chloride content than artesian water yielded by wells drawing from deeper zones. Also, southwest of Bunnell, artesian water yielded by wells drawing from the upper 50 feet of the limestone of Eocene age has a lower chloride content than water yielded by wells drawing from certain zones of the younger deposits.

One of the most important water problems facing the county is the danger that water may move from highly mineralized zones and contaminate the producing zones as withdrawals from wells are increased. Analyses of periodically collected water samples show that the chloride content of the artesian water from some wells increased during the spring growing season, when the withdrawal of artesian water for irrigation was greatest and water levels were lowest. Figure 10 shows the relation between the chloride content of the water and the water level in a well near Codys Corner. It also shows that a 5-foot drop of the water level was accompanied by a temporarytwofold increase of the chloride content. Figure 11 shows the relation between the fluctuations of water level in a well west of Bunnell and the fluctuations of chloride content in the water of a nearby well. A water-level decline of about 10 feet resulted in a sevenfold increase in chloride content, from about 300 to $2,100 \mathrm{ppm}$.

\section{SUMMARY AND CONCLUSIONS}

During the first year of the investigation of the groundwater geology and hydrology of Flagler County the following things were done:

1. Pertinent information on 261 wells was collected for use in preparing geologic and hydrologic maps of the county.

2. Water samples from 163 wells and springs were analyzed for use in describing the chemical quality of ground water throughout the county.

3. Deep-well sampling equipment was used to collect water samples for determining the chloride content of water at various depths in a well. 

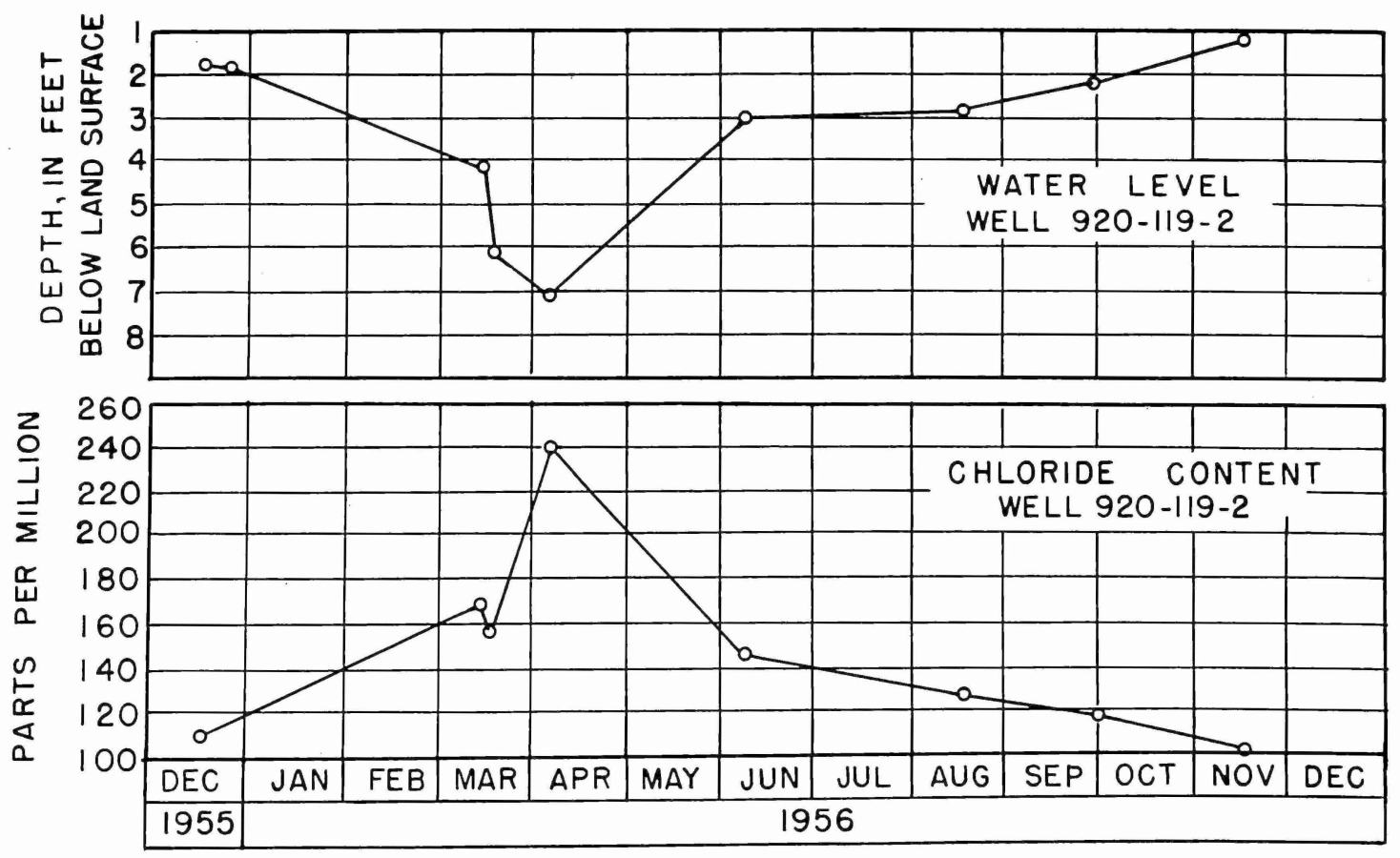

Figure 10. Graph showing the relation between the chloride content of the water and the water level in well 920-119-2 near Codys Corner. 


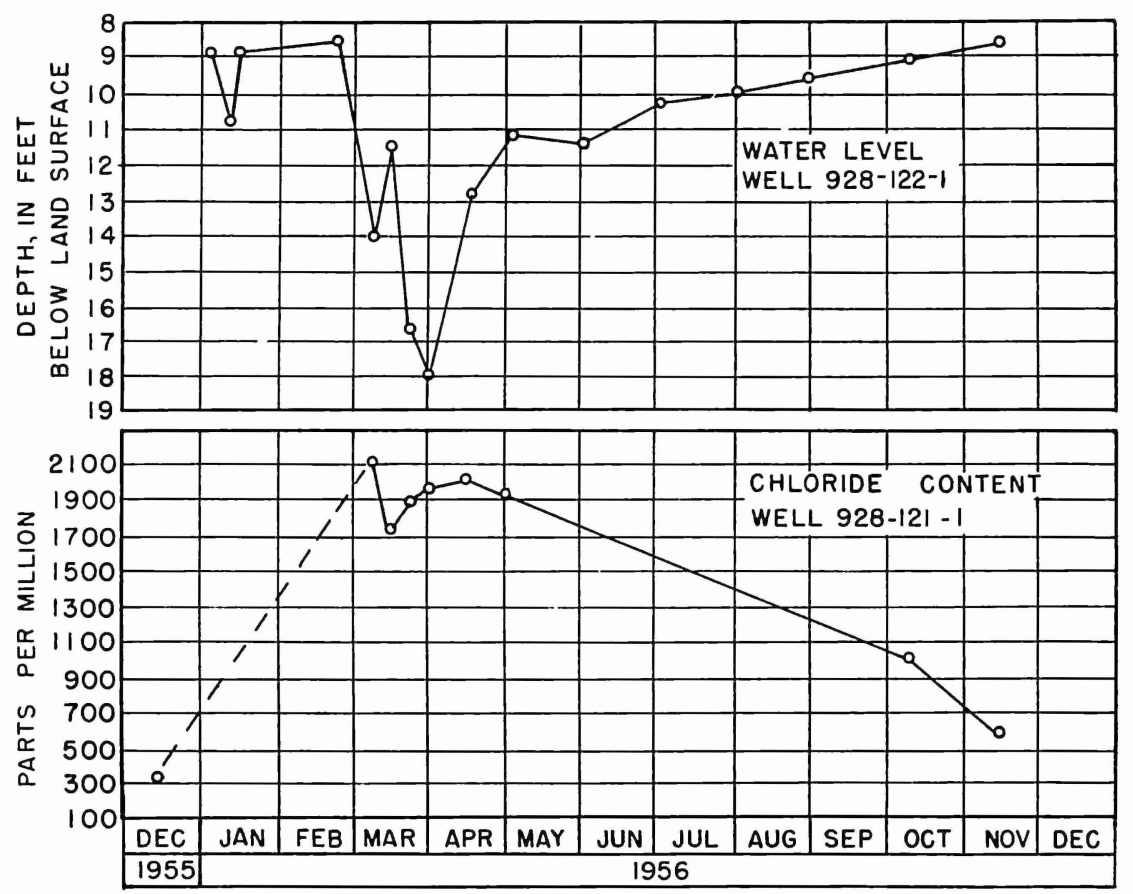

Figure 11. Graph showing fluctuations of water level in well 928-122-1 and the chloride content of the water in well 928-121-1, west of Bunnell. 
4. Fluctuations of chloride content and water level in 24 wells throughout the county were recorded.

5. This report was prepared, summarizing all available facts concerning the ground-water resources of the county.

As the investigation is incomplete at this time, available data are not adequate for final conclusions concerning the ground-water problems confronting the county. However, results obtained so far can be summarized as follows:

1. The principal source of ground water in Flagler County is a thick section of limestone whose top lies at depths ranging from 50 to 150 feet. The 50 to 150 feet of deposits above the limestone consist predominantly of sand, clay, and shells. These overlying deposits have not been differentiated in this report, but records from a few wells show that impermeable beds in the se overlying deposits confine the water in the limestone, under pressure, in most or all areas of the county. Beds of sand and coquina in the overlying deposits yield water of generally low mineral content to a few screened wells in the county.

2. Some of the ground water in Flagler County is obtained from rain that falls on recharge areas in Volusia and Putnam counties, but there are areas of recharge in Flagler County also, particularly near Espanola and Favorita. Natural discharge of ground water in Flagler County takes place through transpiration by plants and the flow from springs along the inland waterway and in the bottoms of Lake Disston and Crescent Lake, and along Haw Creek and its tributaries.

3. In recent years, rainfall has been deficient in the western part of the county and the artesian head has declined about three feet at Bunnell. The decline may have resulted from a deficiency in rainfall and allowed the salvage of recharge formerly rejected. 
4. The chloride content of water from artesian wells in Flagler County ranges from less than $100 \mathrm{ppm}$ in recharge areas to more than 2,000 ppm southwest of Bunnell. In some areas the chloride content of the water in certain wells changes with depth and time. West of Bunnell, the ground water of highest chloride content comes from some of the deeper wells, whereas southwest of Bunnell the ground water of highest chloride content comes from some of the shallower wells. West of Bunnell, and near Codys Corner, the chloride content of water from certain.artesian wells is highest when the withdrawal of ground water is greatest and water levels are lowest.

The results of the investigation to date show that supplies of fresh ground water may not be available southwest of Bunnell, and that present supplies in some farming areas may be subject to serious contamination by the intrusion of highly mineralized ground water. Therefore, future studies in Flagler County will emphasize mapping areas of such mineralized water in greater detail and determining the conditions that influence its movement. The following work will be done:

1. A study will be made of well cuttings to determine the position and thickness of the different geologic formations, especially to determine their division into water-bearing beds (aquifers) and confining beds (aquicludes).

2. Electric logs and test borings will be made to add to the information on position and thickness of water-bearing zones and confining beds.

3. Water from selected wells will be collected with deep-well sampling equipment to determine the quality of water in each zone.

4. The altitudes of measuring points on water-leve1 observation wells will be determined for use in mapping the piezometric surface in greater detail. 
5. Quantitative studies including pumping tests will be made to measure the recharge and discharge rates and the water-transmitting and storing capacities of aquifers.

6. Data on the use of ground water will be collected in order to estimate the rate of withdrawal. This information will be used, in conjunction with data on water levels, the water-transmitting and storing capacity of the aquifer, and chemical quality to predict the effect of increased withdrawal on water levels and quality of water. 


\section{REFERENCES}

Black, A. P.

1951 (and Brown, Eugene) Chemical character of Florida's waters - 1951: Florida State Board Cons., Div. Water Survey and Research, Paper 6.

Brown, Eugene (see Black)

Collins, W. P.

1928 (and Howard, C.S.) Chemical character of waters of Florida: U.S. Geol. Survey WaterSupply Paper 596-G.

Cooke, C. w.

1945 Geology of Florida: Florida Geol. Survey Bull. 29.

Howard, C.S. (see Collins)

Leutze, Willard P. (see Wyrick)

Leve, G. W.

1956 Interim report on the ground-water resources of Putnam County, Florida:Florida Geol. Survey Inf. Circ. 15 (in press).

Stringfield, V. T.

1936 Artesian water in the Florida peninsula: U.S. Geol. Survey Water-Supply Paper 773-C.

Tarver, G. R.

1956 Interim report on the ground-water resources of St. Johns County, Florida: Florida Geol. Survey Inf. Circ. 14 (in press).

Vernon, R. O.

1951 Geology of Citrus and Levy counties, Florida: Florida Geol. Survey Bull. 33.

Westgate, P. J.

1950 Effects of soluble soil salts on vegetable production at Sanford: Florida State Hort. Soc. Proc., Oct. - Nov. 1950. 
Wyrick, Granville G.

1956 (and Leutze, Willard P.) Interim report on the ground-water resources of the northeastern part of Volusia County, Florida: Florida Geol. Survey Inf. Circ. 8. 

